\title{
PM specific methods for recycling the fine and ultra-fine machining chips
}

\author{
Cristian Dragos VIDU'), Mariana LUCACl'), Gheorghe Mircea MATACHE ${ }^{3)}$
}

\author{
1) METAV S.A.- Aviation Metallurgy, Central Laboratory, Nondestructive Testing Laboratory, 16 -18 Zapada Mieilor \\ St., PO 18, 71529 Bucharest-1, Romania \\ 2) METAV S.A. - Aviation Metallurgy, Research Department, Powder Metallurgy Research, 16 -18 Zapada Mieilor \\ St., PO 18, 71529 Bucharest-1, Romania \\ 3) METAV S.A. - Aviation Metallurgy, General Manager, 16 - 18 Zapada Mieilor St., PO 18, 71529 Bucharest-1, \\ Romania
}

\begin{abstract}
The paper presents a simple method to recycle the bearing steel scrap in view to recover the solid part and to use it as additive in sintered friction materials. The method consists of treating and removing of oils, water and surface oxide film. The recovered powders consist of a mixture of metallic and nonmetallic particles. The amount and the chemical composition of the non-metallic part vary with the type and the quality of the grinding wheel. The recovered powder mix was used as such or in the composition of some friction materials, in a proportion of 80 wt\%. The obtained results suggest the recovered powders can be used in the following fields: 1) metallic parts as limit- switcher or spacers; 2) sintered friction materials; 3 ) friction additive for the organic matrix friction materials.
\end{abstract}

KEY WORDS: bearing steel slimes, recovery, recycling, sintered materials, friction materials.

\section{Introduction}

Recovery and reuse of the fine and ultra-fine machining metal scrap, either in a fluid or a semi-fluid state, implies to solve some problems related to the raw material and the implicit final product cost reduction, as of the powder consumption and also those related to the storage space and to the environment pollution reduction.

The great producers of such scrap are in fact producers of parts requiring a high degree of surface finishing, producers interested to use their own scrap [1].

The use of this type of scrap aims on one side to reduce the height and the areas necessary to the storage, with all the related problems - investment, exploitation, transport, abandon and environment protection - and on the other side the rational use of material resources by re-introducing into the economic circuit a great enough amount of metallic material comprised by the scrap [2].

The exploitation of the metal scrap can be applied in the following circumstances: when the scrap is used indoors, when the scrap use is economically efficient, and when the environment is to be protected, the cost to be reduced as well as the storage area, regardless the economic factor.

In a proportion of $100 \%$ this scrap is not recoverable in our country. The metallic material of the solid part of this scrap is estimated to be approximately $60-70 \%$, the rest being a nonmetal part from the grinding wheels.

\section{Experimental Procedure}

Three types of slimes containing bearing steel, which come from three types of grinding machines (semi-fine: Slime I; fine: Slime II; ultra-fine: Slime III) where used. Table 1 gives the chemical compositions of these slimes. It is necessarily to collect the slimes separately in containers that are labeled with steel grade, grinding type and quality of the grinding wheels. This procedure should be done in order to have a rigorously control over the slime types that will be subsequently recycled for recovering the solid part.

Table 1. Chemical compositions of the slimes (\%wt)

\begin{tabular}{|l|c|c|c|c|c|c|}
\hline Type & $\mathrm{Fe}$ & $\mathrm{Cr}$ & $\begin{array}{c}\text { Abra- } \\
\text { sive }\end{array}$ & Oil & $\begin{array}{c}\text { Moi } \\
\text { sture }\end{array}$ & $\begin{array}{c}\text { Loss } \\
\text { in } \mathrm{H}_{2}\end{array}$ \\
\hline Slime I & 84 & 1.00 & 11 & 5.71 & 42.1 & 26.1 \\
\hline Slime II & 86 & 1.15 & 11 & 7.00 & 34.2 & 26.08 \\
\hline Slime III & 80 & 1.00 & 16 & 6.61 & 27.0 & 14.05 \\
\hline
\end{tabular}

To use the solid part of this type of scrap, we have to apply a number of operations for removing the moisture, the oils and the surface oxide film of the metal particles. Table 2 presents the flow chart for recovering the solid part of this scrap. 
Table 2 Recovery technology for the solid part of the slimes

\begin{tabular}{|c|c|c|}
\hline Operation & $\begin{array}{l}\text { Operation } \\
\text { parameters }\end{array}$ & Equipment \\
\hline decant & $t=1-2$ hours & metallic bowl \\
\hline dry & $\begin{array}{l}\mathrm{t}=3-4 \text { hours } \\
\mathrm{T}=100-125^{\circ} \mathrm{C}\end{array}$ & $\begin{array}{l}\text { metallic treys, } \\
\text { furnace }\end{array}$ \\
\hline $\begin{array}{l}\text { de-aggre } \\
\text { gation }\end{array}$ & $\begin{array}{l}\mathrm{t}=1-2 \text { hours } \\
\text { filling degree } 1 / 3 \\
\text { speed ratio }=25-30 \\
\mathrm{rpm} \\
\text { material/balls ratio } \\
2 / 1\end{array}$ & ball mill \\
\hline De-grease & $t=0.5-1$ hour & metallic bowl \\
\hline dry & $\begin{array}{l}t=1 \text { hour } \\
T=50-60^{\circ} \mathrm{C}\end{array}$ & $\begin{array}{l}\text { metallic bowl, } \\
\text { furnace }\end{array}$ \\
\hline De-oxidize & $\begin{array}{l}\mathrm{t}=1 \text { hour } \\
\mathrm{T}=1150^{\circ} \mathrm{C} \\
\mathrm{H}_{2} \text { atmosphere } \\
\text { flow rate } 250 \mathrm{l} / \mathrm{h} \\
\text { overpressure }=0.1 \\
\text { barr }\end{array}$ & $\begin{array}{l}\text { electric } \\
\text { furnace, } \\
\text { metallic treys } \\
\text { refractors }\end{array}$ \\
\hline grinding & $\begin{array}{l}\mathrm{t}=0.2-1 \text { hours } \\
\text { filling ratio } 1 / 3 \\
\text { speed ratio }=25-30 \\
\mathrm{rpm} \text { material } / \text { balls } \\
2 / 1\end{array}$ & ball mill \\
\hline sort & $\begin{array}{l}\mathrm{t}=0.2-0.4 \text { hours } \\
\text { manually/mechanic } \\
\text { ally }\end{array}$ & $\begin{array}{l}\text { metals sieves } \\
\text { (openings } 0.2 \\
\text { mm) }\end{array}$ \\
\hline packaging & manually & - \\
\hline
\end{tabular}

For these treating operations to be effective, it is important to be applied to fresh slimes. Generally, this scrap is more or less fluid paste made of metal and nonmetal parts, with a felt-like appearance. Depending on the grinding type and on the nature and quality of the grinder discs, the scrap contains more or less nonmetallic particles (abrasive) and fluid. After the moisture removal, the slimes show up as big spongy or felt-like lumps of dull-red or blue color depending on the oxidation degree and the type of surface oxide formed. The metal particles have an elongated shape: bean skins, comas (thicker at one end, thin to the other). The nonmetal particles are polyhedral in shape. The particle size differs with the grinding type and the grinder discs quality. The average particle size is of $30-40 \mu \mathrm{m}$ and the powder specific surface is within the range from 0.5 to 1 $\mathrm{m}^{2} / \mathrm{cm}^{3}$. Table 3 shows the chemical composition of the tested slimes.

Table 3. Chemical composition of the slimes (\%wt)

\begin{tabular}{|c|c|c|c|}
\hline Metallic part & $\begin{array}{c}\text { Non-metallic } \\
\text { part }\end{array}$ & Oil & Moisture \\
\hline $31-59$ & $10-17$ & $6-7$ & $25-45$ \\
\hline
\end{tabular}

After the water and the oil were removed, the scrap is a mechanical mixture containing one part nonmetal to three parts metal. The main physical characteristics of the mix are shown in Table 4.
Table 4. Physical characteristics of the powder mixes obtained after the slimes treatment, compared with those of iron powder

\begin{tabular}{|l|l|l|l|l|l|l|}
\hline $\begin{array}{l}\text { Powder } \\
\text { type }\end{array}$ & \multicolumn{3}{|c|}{$\begin{array}{l}\text { Grain distribution } \\
\text { size } \\
\%\end{array}$} & $\rho_{\mathrm{a}}$ & $\mathrm{v}$ \\
\cline { 2 - 7 } & \multicolumn{3}{|c|}{$\begin{array}{l}\mathrm{g} / \mathrm{cm}^{3} \\
\text { Opening } \\
\text { size }\end{array}$} & $\mathrm{s} / 50 \mathrm{~g}$ \\
\hline & $\begin{array}{l}15 \\
0\end{array}$ & $\begin{array}{l}150 \\
-75\end{array}$ & $75-45$ & 40 & & \\
\hline Slime I & 20 & 20 & 25 & 35 & 1.50 & 45 \\
\hline Slime II & 20 & 15 & 20 & 45 & 1.70 & 40 \\
\hline Slime III & 20 & 10 & 15 & 55 & 1.90 & 37 \\
\hline $\begin{array}{l}\text { Slime } \\
\text { I+II+III }\end{array}$ & 20 & 15 & 20 & 45 & 2.00 & 35 \\
\hline $\begin{array}{l}\text { SC 100- } \\
24\end{array}$ & 1 & $\begin{array}{l}25- \\
40\end{array}$ & $35-50$ & $20-35$ & 2.55 & 30 \\
\hline $\begin{array}{l}\text { NC 100- } \\
24\end{array}$ & 1 & $\begin{array}{l}45- \\
60\end{array}$ & $20-35$ & $15-30$ & 2.40 & 30 \\
\hline $\begin{array}{l}\text { FREMS } \\
\text { 160-24 }\end{array}$ & 10 & $\begin{array}{l}60- \\
80\end{array}$ & $15-35$ & - & 2.40 & - \\
\hline
\end{tabular}

The oxygen content of the powders obtained from the slime is within the allowed values of maximum $0.5 \%$. The best characteristics are those of the powders produced from slime III, coming from gear super-finishing even if their oxygen content is higher.

\section{Results}

The powder mix recovered from slime was tested to establish the pressing and sintering behavior. The compacting pressure used was: 400,450 and $500 \mathrm{MPa}$. Sintering was applied in a tunnel furnace under an endothermic gas atmosphere at the following parameters: $\mathrm{T}=1100^{\circ} \mathrm{C}$ and band speed of $0.7 \mathrm{~m} / \mathrm{h}$. The green density of the samples varied with the applied pressure and the type of recovered powder used (Fig.1)

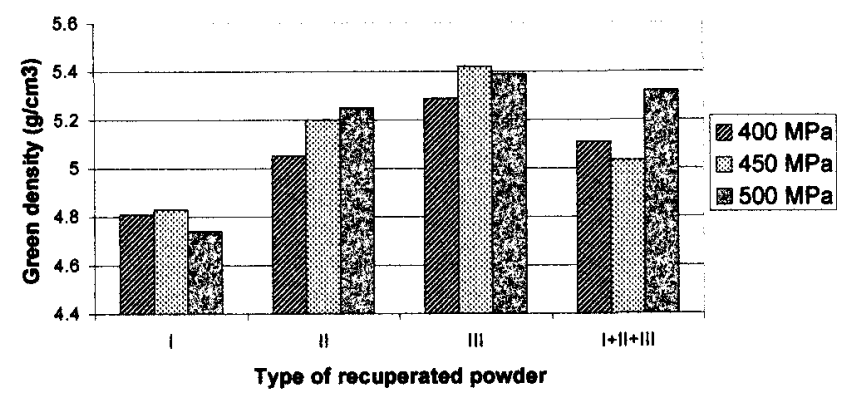

Fig.1 The green density of the compacts made of recovered powder

The highest green density values are of the samples obtained from the powder recovered from slime III. The green density values increased as Slime I, Slime II, Slime I+II+III, Slime III, the same order obtained for the as 
sintered densities. As a general remark, the volume contraction and the densification (Fig.2) take place during sintering the powders recovered from slime.

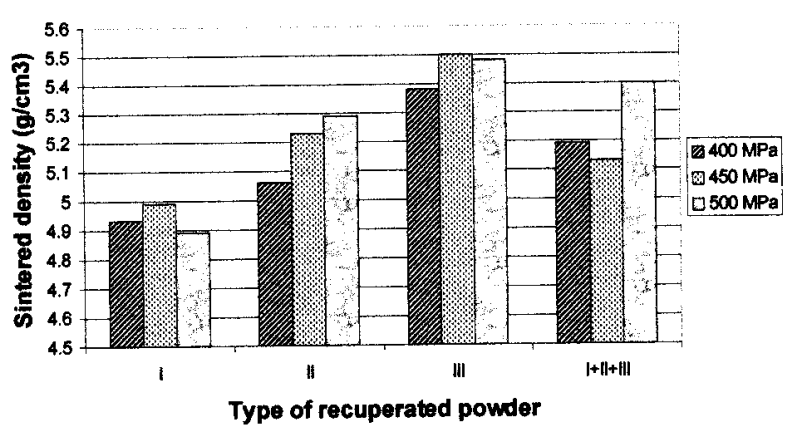

Fig.2 Sintered density of the samples made of recovered powders.

The hardness of the sintered compacts showed an inverse tendency (Fig.3). The increasing order of the hardness values is: Slime III, Slime II, Slime I and Slime I+II+III. The values of hardness were within the range from 70 to $100 \mathrm{HB}$.

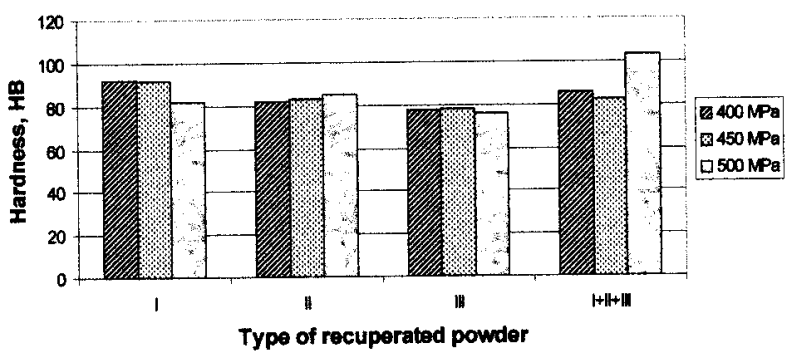

Fig.3. Hardness of the samples made of recovered powders

The bending strength was of $170-200 \mathrm{~N} / \mathrm{mm}^{2}$ for all the types of obtained recovered powders. These results lead to the conclusion that the mix of recovered powders has a good pressing-sintering behavior and can be used as such to obtain metallic parts of a good mechanical resistance, or in the composition of some friction materials. The compositional nonhomogeneity can be eliminated by a homogenization, using equal amounts of the three powders, before making up a material for a certain purpose.

From the point of view of the economic effort necessary to recover these materials, the computation made at the 1999 level for laboratory conditions, evidenced a total cost of $0.76 \$ / \mathrm{Kg}$ of recovered powder of which $0.61 \$$ represent the cost necessary for the materials, power, utilities, etc and $0.15 \$$ represent the labor necessary.

Taking into account that the cost of $1 \mathrm{Kg}$ of iron powder is about $1.8-2 \$ / \mathrm{Kg}$, using the recovered powder in the compositions of some materials can generate important economies related to the cost of the raw materials and implicit of the final product.

Starting from the prior conclusions, four sintered friction material compositions based on recovered powder from slime were produced (Table 5).
Table 5. The chemical compositions of the friction materials (\%wt)

\begin{tabular}{|l|c|l|c|c|c|}
\hline $\begin{array}{l}\text { Material } \\
\text { type }\end{array}$ & $\begin{array}{l}\text { Recovered } \\
\text { powder }\end{array}$ & $\mathrm{Cu}$ & $\mathrm{SiC}$ & $\mathrm{SiO}_{2}$ & Graphite \\
\hline \multicolumn{6}{|c|}{ Grain size distribution $(\mu \mathrm{m})$} \\
\hline & $<50$ & $<200$ & $<120$ & $<120$ & $120-300$ \\
\hline ARF 1 & 80 & 4 & 3 & 5 & 8 \\
\hline ARF 2 & 80 & 4 & 8 & - & 8 \\
\hline ARF 3 & 80 & 4 & - & 8 & 8 \\
\hline ARF 4 & 81 & 4 & 5 & 4 & 6 \\
\hline
\end{tabular}

The powder mixtures presented in Table 5 were homogenized for one hour after the nonmetallic raw materials were dried for one hour at $140{ }^{\circ} \mathrm{C}$ and then they were sieved to retain the required grain size fraction. The chosen compacting specific pressure was of $500 \mathrm{MPa}$ and the pressing force was of unidirectional type in a single step. Sintering was done in a tunnel furnace under a controlled atmosphere (endothermic gas) at $\mathrm{T}=1100{ }^{\circ} \mathrm{C}$ at a band speed of $0.7 \mathrm{~m} / \mathrm{h}$. The sintered friction materials presented lower densities then the green ones indicating that inside the materials there are active that phenomena (liquid phase sintering, formation of a solid solution of copper in iron, carbon in iron, etc.) that induce expansion of the materials. The obtained materials had hardness within the range from 40 to $80 \mathrm{HB}$.

The trybological characterization of the materials was also performed in order to establish the fields of use of these materials and the optimum operational parameters. The friction-wear characteristics were determined at different loads $(4,8,12 \mathrm{daN})$ and sliding speeds $(8,14,22$ $\mathrm{m} / \mathrm{s})$.

Regardless the type of recovered powder, the friction coefficient values are within the range from 0.33 to 0.52 for all the forces and sliding speeds used, these values recommending their use for braking systems and dry clutches.

The materials had different wear behavior depending on the testing parameters and on the chemical composition. For a sliding speed $8 \mathrm{~m} / \mathrm{s}$ (Fig.4) the depth wear increases with the applied load, the worst behavior being of the ARF3 material, for all the types of recovered powder used.

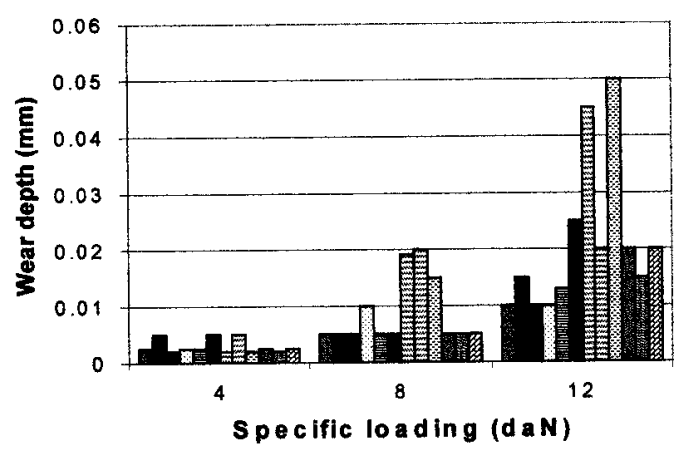

ARF 11 UARF 1 H DARF1 ill DARF 2 I

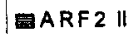
GARF 2 III EARF 3 I ERF 3 II ARF 3 it: ARF 4 I ARF 4 II ARF 4 III

Fig. 4. Variation of the wear depth of the sintered friction materials as a function of the specific loading, at $8 \mathrm{~m} / \mathrm{s}$ sliding speed 
The best wear behaviors are for ARF 1 and ARF4, for all the types of recovered powder used. The ARF1 (Fig.5), ARF2 (Fig.6) and ARF4 (Fig.7) materials present good wear characteristics and can be recommended to equip the braking systems of some car types.

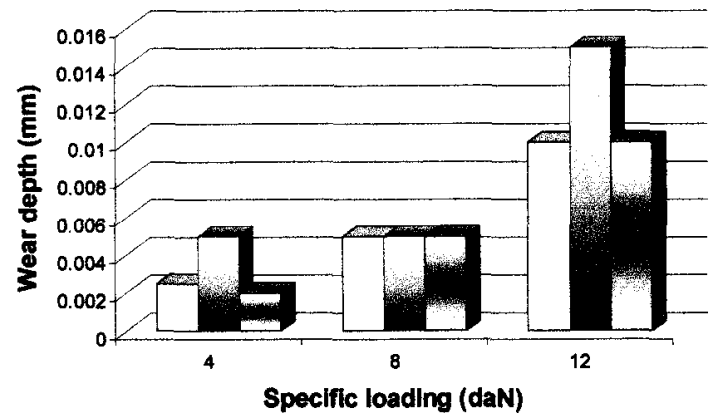

Fig.5. Variation of the wear depth of the ARF1 material as a function of the sliding speed, at different specific loading, for all the types of recovered powder

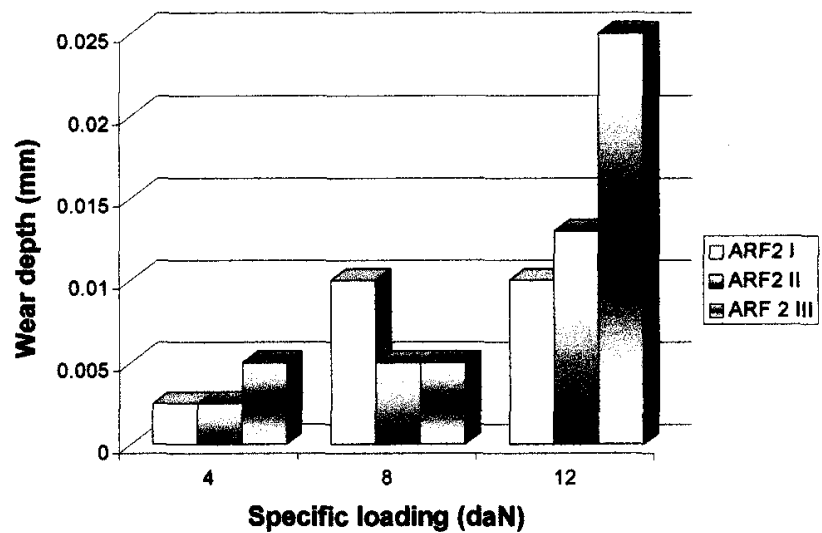

Fig.6. Variation of the wear depth of the ARF2 material as a function of the sliding speed, at different specific loading, for all the types of recovered powder

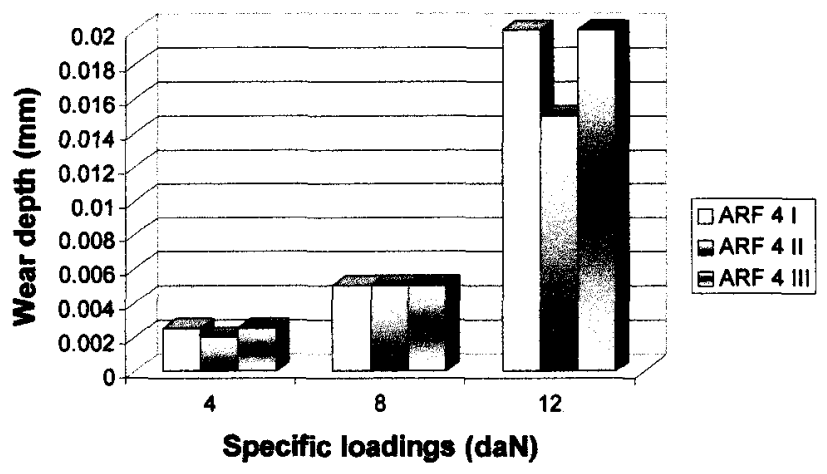

Fig.7. Variation of the wear depth of the ARF4 material as a function of the sliding speed, at different specific loading, for all the types of recovered powder

\section{Conclusions}

The technology to recover the solid part of the slimes resulting from fine and ultra-fine machining of the bearings is simple and does not required costly equipment.

Use of the recovered powders to produce low mechanically loaded parts, such as limit-switches, spacers, allows for the complete reuse of this scrap. Using additions such as $(\mathrm{Cu}, \mathrm{Fe}, \mathrm{Mo}, \mathrm{Ni}$, and graphite) increases the strength of the metal matrix and higher strength materials can also be obtained.

One of the applications of metallo-ceramic materials obtained by sintering from the recovered powders is for the braking systems or for the dry clutches, due to their good friction-wear characteristics.

Also, the recovered powders can be used as fillers, to obtain friction materials with an organic matrix.

The fact that the recovered powder costs only $0.76 \$ / \mathrm{kg}$ leads to important economies in terms of the raw material cost, leading to a cost reduction of the final product, too.

The slime treating to recover the solid part also diminishes the environment pollution (soil and freatic water infiltration of organic impurities) leading the impurities to the channeling system.

\section{REFERRENCES}

A.A Maurice, H. Howes - Recycling Metallic Scrap into High quality Components, Part.1

P. Tameta - Halde pentru depozitarea slamurilor, cenusilor zgurelor, sterilelor si deseurilor menajere, Ed.Tehnica 1982 